common with age. This tendency is clearly indicated in Figs. 1 and 2 . The greater incidence of this condition among male children is well known and also, shows in our series. In the case of whipworm, however, infestation rates appear to be approximately the same irrespective of the ages of the children examined.

As stated above three $(1.1 \%)$ children born in the United Kingdom to immigrant parents had certainly become infested in this country, and four others might have become infested here but are more likely to have become infested in visits to their parents' homeland. The risk of cross-infestation in these children must be much higher than in children born in the United Kingdom to English parents because they live in greater social proximity to infested immigrants arriving here.

Perhaps the most unexpected case was that of hookworm occurring in a child born in the United Kingdom to West Indian parents. Inquiry revealed that the boy was more than usually inclined to play in soil and also that he was left for long periods with minimal supervision while his mother was at work. Nevertheless it does indicate that hookworm ova can embryonate even in the climatic conditions of Northern England. Two other cases have been recorded (Buckley and Pester, 1965), indicating that further investigation is needed.

The effect on worm infestation of residence in Great Britain varies according to the particular helminth concerned. In the case of hookworm it is clear that the degree of infestation diminishes gradually, and we found very little in children who had been here for four or more years. The longest period of survival in our series is in a child who arrived in this country in 1957 and whom we presume not to have been infested since arrival.

The same does not appear to be true of other infestations, and, in the case of whipworm in particular, the rates are as high after five years' residence here as they are among children who have newly arrived. Whipworm was found in children who had been in Great Britain for 6, 8, and 12 years respectively, and roundworm also has been found in a child resident here for eight years. Of the 36 cases of dwarf tapeworm in our series the rate of infestation appears to diminish with residence in Great Britain, though it is possible that limited cross-infestation is taking place.

\section{Summary}

A total of 1,317 children of Commonwealth immigrants have been examined for intestinal helminth infestation. A stool was examined from a single direct smear, and $18.6 \%$ of the children were found to be infested. The rate of infestation with different parasites is recorded, as is the country of origin of the immigrants. The incidence of hookworm and whipworm at different ages is compared.

Seven cases of infestation in children of immigrants born in the United Kingdom are recorded, and three of these children had never been outside the United Kingdom. The proportion of children infested with hookworm seems to diminish proportionately to the time they have been resident in Great Britain, but this is not the case with whipworm infestation.

We wish to thank Dr. J. Douglas, Medical Officer of Health, Bradford, for his interest and encouragement.

\section{REFERENCES} Bras, G., Richards, R. C., Irvine, R. A., Milner, P. F. A., and Ragbeer,

Buckley, J. J. C., and Pester, F. R. N. (1965). Brit. med. 7., 2, 106. Patel, J. C. (1954). Indian f. med. Res., 42, 281.

Shrivastav, J. B. (1954). Ibid., 42, 497.

World Health Organization (1964). Techn. Rep. Ser., No. 277, p. 6

\title{
Psychiatric Referrals from Courts and Prisons*
}

\author{
JOHN S. BEARCROFT, $\dagger$ M.B., M.R.C.P., D.P.M. ; in collaboration with MARY D. DONOVAN $\ddagger$
}

\author{
Brit. med. F., 1965, 2, 1519-1523
}

The introduction of the Mental Health Act, 1959, has brought an increase of prison referrals to consultant psychiatrists. The increase is more apparent in some areas than others, and there is a great variation in the numbers of court referrals seen and treated in different psychiatric hospitals. Factors involved are multiple and reflect the changes since the 1959 Act, including changes of policy in psychiatric hospitals. In a previous study West, Bearcroft, and Smith (1960) showed that men were remanded in custody rather than on bail for psychiatric reports and on social rather than psychiatric grounds; the number of men remanded on bail to psychiatric out-patient departments is still small (Scott, 1964). Because of the precise catchment area of most psychiatric hospitals, it is possible to assess the psychiatric morbidity of the mentally disordered in conflict with the law from those remanded in custody for a psychiatric report. The catchment area of Long Grove Hospital is the East End of London and it has a particularly heavy load of psychiatric referrals from the courts; most of these are men remanded in custody.

\footnotetext{
* Part of an M.D. thesis, University of Newcastle upon Tyne.
t Consultant Psychiatrist, Long Grove Hospital, Epsom, and Kingston
Hospital.
₹ Social worker. ‡ Social worker.
}

In the course of one year (1963) 146 men were referred to me for examination and report to the courts or Home Office ; the handful of female offenders are not considered in this study. These 146 men represented 139 individuals; a description is made in terms of diagnoses, offences and criminal background, the recommendations to the courts, and the ultimate decisions of the courts. Their disposal by the courts and their outcome are correlated with various social and personal factors. The psychiatric assessment was recorded at the time of the initial interview where possible, and additions and confirmation were obtained later, especially in those admitted to hospital. Those offenders who were referred to hospital were mostly admitted to Long Grove Hospital under my care.

Rollin (1963) described a series of admissions from the courts to Horton Hospital in 1961. He then held the view that the fivefold increase in male offenders admitted in a year to Horton Hospital following the Mental Health Act presented a serious social problem. He discussed such factors as the number of immigrants into this country, both coloured and white, who are chronic psychotics on arrival, and the increased freedom allowed to patients by the Mental Health Act, 1959 . He believed that the major source of psychiatric offenders was the mental hospital. 


\section{Medical and Social Assessment}

The reasons for the referral of these men are set out in Table I. The great majority of the 146 men were seen and

TABLE I.-Source and Reasons for Referral
Source of referral:
From the courts
", prison medical officers
.

examined at the request of the courts and were interviewed while on remand in custody. They were referred mainly because of a past psychiatric history (81), and, in approximately equal numbers, because of behaviour in court (34) and behaviour in prison (31). Understandably, the latter were referred by prison medical officers. Five men were seen while serving a prison sentence; these included two who were mentally ill, one who was subnormal, and two psychopaths. In most of these cases either the man's residence or the situation of the remanding court was in the catchment area of Long Grove Hospital. A large proportion, it should be noted, had no fixed abode and many had wandered into the catchment area, which is, in parts, a well-known haunt of social derelicts, vagrants, and psychopaths.

A classification of the mental disorder of the men referred was made in accordance with the Mental Health Act, 1959. The diagnoses are recorded in Table II. Total diagnoses are shown in excess of 146 because of multiple diagnoses in many patients. Multiple diagnoses occurred in $22 \%$, and the most common association was a depressive reaction with psychopathy. In $79 \%$ of the 146 referrals the primary diagnosis was either schizophrenia $(40 \%)$ or personality disorder $(39 \%)$. Personality disorders included psychopathy $(25 \%)$ and various neurotic reactions $(14 \%)$. This accords with a suggestion by Brooke (1962), in her studies of mental hospital admissions, that increasing numbers of persons with personality disorders are finding their way into hospitals. Some of these personalitydisorder cases had had a previous diagnosis of schizophrenia.

\begin{tabular}{|c|c|c|c|c|}
\hline \multicolumn{3}{|c|}{ Diagnosis } & Total Diagn’ssis & Primary Diagnosis \\
\hline $\begin{array}{l}\text { Schizophrenia } \\
\text { Manic depression } \\
\text { Neurotic reaction } \\
\text { Organic/senile } \\
\text { Psychopathy } \\
\text { Subnormal . } \\
\text { Nil . . . }\end{array}$ & $\begin{array}{l}\because \\
\therefore \\
\therefore \\
\therefore\end{array}$ & $\begin{array}{l}\because \\
\because \\
\because \\
\therefore\end{array}$ & $\begin{array}{r}58 \\
10 \\
31 \\
5 \\
51 \\
23 \\
8\end{array}$ & $\begin{array}{r}58 \\
10 \\
21 \\
4 \\
36 \\
9 \\
8\end{array}$ \\
\hline Total & . & $\ldots$ & 186 & 146 \\
\hline
\end{tabular}

Primary diagnosis refers to the predominant mental disorder. In many cases Primary diagnosis refers to the predominant mental disorder. In many cases
there was more than one diagnosis. "Total diagnoses " refers to all categories of there was more ther found.
disorder

Most of the 58 schizophrenic patients were floridly ill at the time of examination, and a great many were hallucinated. In eight of them it was a first illness of at least three years' duration; they were socially isolated and degraded, and had had no treatment. In nine schizophrenia was associated with subnormality or an organic state; more than half had undergone leucotomy or had had an old head injury. Even where the schizophrenia seemed uncomplicated by other diagnoses (49 men) there were additional and often intractable social problems. Table III shows that only $14.5 \%$ of this group had

\begin{tabular}{|c|c|c|c|c|}
\hline Abode & Born in U.K. & Born in Ireland & Migrant* & Total \\
\hline $\begin{array}{l}\text { ixed abode } \\
\text { lo fixed abode }\end{array}$ & $\begin{array}{l}14.5 \% \\
31.3 \%\end{array}$ & $\begin{array}{r}10.4 \% \\
6.3 \%\end{array}$ & $\begin{array}{l}10 \cdot 4 \% \\
27 \cdot 1 \%\end{array}$ & $\begin{array}{l}35 \cdot 4 \% \\
64.6 \%\end{array}$ \\
\hline Total & $45 \cdot 8 \%$ & $16 \cdot 7 \%$ & $37.5 \%$ & $100 \%$ \\
\hline
\end{tabular}

- The place of birth is other than in the United Kingdom or Ireland. a fixed abode and were born in the United Kingdom ; $37.5 \%$ were immigrants, mostly coloured. A large number of the homeless schizophrenics appeared to have left reasonable homes because of their illness.

The manic-depressive group consisted of nine hypomanic patients and one depressive (a man convicted of manslaughter who had also attempted suicide). The 21 neurotic reactions included anxiety and hysterical, paranoid, and depressive reactions. In these the neurotic reactions seemed primary in that, though a defect of personality was presupposed, it did not amount to psychopathy ; these men had made relationships in the past, could exist at a reasonable level in society, and generally were a less criminal group, judging from their previous criminal records, than other diagnostic groups. In another 10 men a neurotic reaction was secondary to a psychopathic disorder. There were four with organic states, including three senile dements and a cerebral syphilitic.

A primary diagnosis of psychopathy was made in 36 men; in this group there was a remarkable lack of stable relationships in the past and an inability to meet the obligations and social expectations of adult life. The inability to cope with any relationship was the most distinguishing feature. Two psychopaths seen while serving a prison sentence were of some interest ; after a period of observation they had been suspected by the prison medical officers of being mentally ill. One proved to be an aggressive psychopath; the other a hysterical psychopath, a long-standing confidence trickster. In 26 the psychopathy was associated with neurotic symptoms or with subnormality. Nine subnormal patients were referred; all were previously ascertained to be educationally subnormal (E.S.N.) and found to have an I.Q. below 70 .

In eight men no diagnosis was made: their apparent mental disorder was explained by considerable social problems. All had no fixed abode, and three (two of them coloured immigrants) had had a mental illness in the past-a schizophreniform reaction. The previous mental illness seemed to have little bearing on the behaviour leading to the offence.

Study of the age distribution indicates that the largest group of offenders were in their $20 \mathrm{~s}$ and $30 \mathrm{~s}$; two-thirds were under 40. They tended to be slightly younger than the overall male admissions to Long Grove Hospital, who in turn were slightly younger than the overall male admissions in the region.

In $22.6 \%$ of referrals there was no previous psychiatric history (Table IV), $77.4 \%$ had been in hospital before, and $17 \%$ had been admitted on more than three previous occasions ; only $20 \%$ had previously been in Long Grove Hospital, and

TABle IV.-Relation between Previous Psychiatric History and Disposal

\begin{tabular}{|c|c|c|c|c|}
\hline & \multicolumn{4}{|c|}{$\begin{array}{c}\text { No. of Previous Admissions to Psychiatric } \\
\text { Hospitals }\end{array}$} \\
\hline & None & $1-3$ & Over 3 & Total \\
\hline $\begin{array}{l}\text { No recommendation } \\
\text { Recommendation not accepted } \ldots \\
\text { Patients refused treatment } \\
\text { Admission to Broadmoor Hospital } \\
\text { " " Long Grove Hospital } \\
\text { "”, other psychiatric } \\
\text { hospitals" }\end{array}$ & $\begin{array}{r}\frac{7}{1} \\
1 \\
20 \\
4\end{array}$ & $\begin{array}{r}18 \\
4 \\
1 \\
1 \\
54 \\
10\end{array}$ & $\begin{array}{r}3 \\
\frac{1}{2} \\
16 \\
3\end{array}$ & $\begin{array}{r}28 \\
5 \\
2 \\
4 \\
90 \\
17\end{array}$ \\
\hline Total & $\begin{array}{c}33 \\
(22 \cdot 6 \%)\end{array}$ & $\begin{array}{c}88 \\
(60 \cdot 2 \%)\end{array}$ & $\begin{array}{c}25 \\
(17 \cdot 2 \%)\end{array}$ & 146 \\
\hline
\end{tabular}

$56 \%$ had been in a hospital other than Long Grove. Of those without a previous psychiatric history $6 \%$ were newly diagnosed schizophrenics, indicating that a section of the public is still slow in availing itself of psychiatric help early enough in the course of serious illness to prevent considerable social disturbance.

In 21 cases where I did not recommend admission there had been a previous admission to a psychiatric hospital, including three with multiple admissions; some of these men had previously been admitted to hospital with an initial diagnosis of 
schizophrenia, changed to psychopathy after a period of observation.

TABLE V.-Relation between Primary Diagnosis and Disposal by the

\begin{tabular}{|c|c|c|c|c|c|}
\hline \multicolumn{2}{|l|}{ Diagnoses } & \multirow{2}{*}{$\begin{array}{c}\begin{array}{c}\text { Whole } \\
\text { Group }\end{array} \\
58 \\
10 \\
21 \\
4 \\
36 \\
9 \\
8 \\
\end{array}$} & \multirow{2}{*}{$\begin{array}{c}\begin{array}{c}\text { Long } \\
\text { Grove } \\
\text { Admissions }\end{array} \\
49 \\
8 \\
16 \\
3 \\
12 \\
2 \\
0\end{array}$} & \multirow{2}{*}{$\begin{array}{c}\begin{array}{c}\text { Admissions } \\
\text { to Other } \\
\text { Hospitals }\end{array} \\
8 \\
2 \\
2 \\
1 \\
4 \\
4 \\
-\end{array}$} & \multirow{2}{*}{$\begin{array}{c}\begin{array}{c}\text { Not } \\
\text { Admitted }\end{array} \\
1 \\
0 \\
3 \\
0 \\
20 \\
3 \\
8\end{array}$} \\
\hline $\begin{array}{l}\text { Schizophrenia } \\
\text { Manic depression } \\
\text { Neurotic reaction } \\
\text { Organic/senile } \\
\text { Psychopathy } \\
\text { Subnormal } \\
\text { Nub } \\
\text { Nil } \quad . .\end{array}$ & $\begin{array}{l}\ldots \\
\cdots \\
\cdots \\
\cdots \\
\cdots\end{array}$ & & & & \\
\hline Total .. & $\ldots$ & 146 & 90 & $21^{\circ}$ & 35 \\
\hline
\end{tabular}

The length of time since discharge from hospital (Table VI) was more than a year in $48 \% ; 3 \%$ had been out for under a week and $3.5 \%$ were still nominally in-patients of hospital, having absconded. The majority of the men referred had spent much of their recent lives in irregular accommodation ; $61 \%$ had no fixed abode and $19 \%$ were of no fixed abode and from outside the U.K. Only $24 \%$ were from the U.K. and had a settled home. Ten per cent. of the homeless were believed to have left good homes because of an estrangement in their families due to illness.

TABLE VI.-Period Since Last Admission to a Hospital of 113 Men with a Previous Psychiatric History

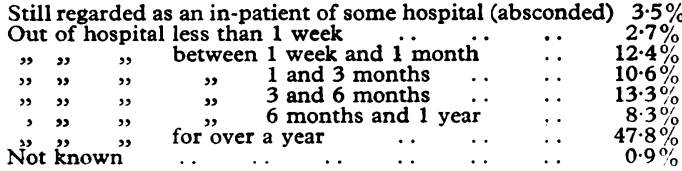

\section{Recommendations : Decisions of Courts}

The recommendations for psychiatric treatment made to the courts included admission to hospital in 118 cases and outpatient treatment in 16 ; no recommendation for treatment was made in 12 cases. Admission to hospital occurred under different sections of the Mental Health Act, as part of a Probation Order (Section 4 Criminal Justice Act, 1948), or informally. The mode of admission (Table VII) was $51 \%$ under Section 60 , Mental Health Act, 1959, 32\% informally (mostly under Section 4, Criminal Justice Act, 1948), and $8 \%$ under Section 25, Mental Health Act, 1959.

Table VII.-Mode of Admission to Different Hospitals

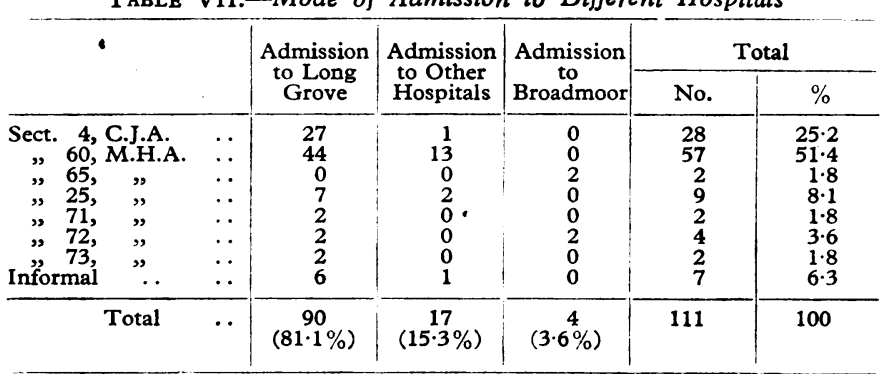

The Mental Health Act, 1959, provides as follows: Section 25 entails a compulsory admission to hospital after recommendation by two doctors; this is commonly used by the courts in non-indictable offences and on release from a prison sentence. Section 60 is a Hospital Order whereby a convicted person may be detained in hospital by the court on the recommendation of two doctors. Sections 71,72 , and 73 involve a transfer to hospital of the mentally sick unfit to plead, serving a prison sentence, or awaiting trial respectively. Section 4 of the Criminal Justice Act, 1948, allows the court to include a period of informal medical treatment as part of a Probation Order.
Section 60 was recommended mostly for men who were floridly ill-admission informally whenever it was thought that there were no grounds for compulsory detention-including many cases of neurotic reaction and psychopaths. In this group it often seemed advantageous to have the additional support of a probation officer for the period following discharge from hospital. Those admitted under Section 25 of the Mental Health Act were men who had been so ill in prison that the need to admit them to hospital was urgent; this was possible with a few cases of non-indictable offences and when the court was prepared to make a conditional discharge. A Section 7.1, involving "Unfitness to Plead," was used in the case of a catatonic schizophrenic who was mute, manneristic, and stuporous, and in another, a florid schizophrenic, where a previous recommendation under Section 60 had been rejected by the court. Four of the five men seen while serving a prison sentence were recommended for transfer to hospital under Section 72 of the Mental Health Act; two were psychopaths transferred to Broadmoor Hospital, two were mentally ill cases admitted to Long Grove Hospital, one was a depressive convicted of manslaughter, and another was a schizophrenic Section 73 was used on two occasions for men who developed acute schizophrenic symptoms while awaiting trial. Eight men showed no psychiatric symptoms when examined. No treatment of any kind was offered to this group and to four psychopaths who were thought to be untreatable.

The recommendation for admission and treatment was accepted by the courts in $92 \%$ of cases. Where the recommendation was rejected the men had to be admitted shortly afterwards, either as transfers from prison on release from prison or during a remand for an immediate subsequent offence; two were schizophrenic, one was a hypomanic, and one was a subnormal man who was sent to prison.

Five men were seen twice and another was seen on three occasions within the year of study; the latter was a psychopath who had had no previous treatment and for whom no recommendation for treatment was made on the first two occasions. When finally, on a third occasion, he seemed very depressed he requested treatment and was recommended for in-patient care, but this was refused by the court. A coloured immigrant with schizophrenia had had a frustrating social problem which was never satisfactorily dealt with and which was thought to aggravate his paranoid and violent behaviour, thus precipitating his second appearance in court and his eventual disposal to Broadmoor Hospital. A subnormal without previous training and two schizophrenics were accepted by the court for treatment in hospital on the second occasion only. A schizophrenic Indian, also subnormal, had not accepted a settled way of life, largely because of cultural reasons, and this continues to bring him into regular conflict with the law.

Apart from the specific requirements of a psychiatric opinion for the court and his access to treatment facilities, the visiting psychiatrist has an opportunity of making contact with many men with personality disorders who are not suitable for inpatient treatment but are in need of support. Many men offered only informal out-patient treatment found their way to the out-patient department after a prison sentence or conditional discharge, etc.

\section{Criminal Background}

In Table VIII the types of offence committed are shown in relation to the diagnosis. All types of offence were found in each diagnostic category, but the most frequent association was a trivial offence against property, such as stealing food or a bottle of milk, with schizophrenia. The serious sexual offences were committed mainly by psychopaths; a small group of schizophrenics were convicted of indecent exposure. Of the offences, $22 \%$ were of a public nature and included, in descending order of frequency, loitering, vagrancy and wandering 
abroad, possession of drugs, insulting behaviour, breach of the peace, drunk-and-disorderly behaviour, begging, forging a prescription, not paying rail fares, breach of probation ; there were two non-indictable offences of using abusive language.

TABLE VIII.-Relation between Type of Offence and Diagnosis

\begin{tabular}{|c|c|c|c|c|c|c|}
\hline \multirow{2}{*}{ Diagnosis } & & \multicolumn{5}{|c|}{ Offences } \\
\hline & & Public & Personal & Property & Sexual & Total \\
\hline $\begin{array}{l}\text { Schizophrenia } \\
\text { Manic depression } \\
\text { Neurotic reaction } \\
\text { Organic/senile } \\
\text { Psychopathy } \\
\text { Subnormal . . } \\
\text { N.A.D. . . }\end{array}$ & $\begin{array}{l}\cdots \\
\because \\
\cdots \\
\cdots\end{array}$ & $\begin{array}{r}14 \\
3 \\
4 \\
0 \\
9 \\
1 \\
1\end{array}$ & $\begin{array}{r}11 \\
2 \\
4 \\
0 \\
6 \\
0 \\
1\end{array}$ & $\begin{array}{r}29 \\
4 \\
12 \\
3 \\
16 \\
8 \\
5\end{array}$ & $\begin{array}{l}4 \\
1 \\
1 \\
1 \\
5 \\
0 \\
1\end{array}$ & $\begin{array}{r}58 \\
10 \\
21 \\
4 \\
36 \\
9 \\
8\end{array}$ \\
\hline Total & . & $\begin{array}{c}32 \\
(21 \cdot 9 \%)\end{array}$ & $\begin{array}{c}24 \\
(16 \cdot 4 \%)\end{array}$ & $\begin{array}{c}77 \\
(52 \cdot 7 \%)\end{array}$ & $\begin{array}{c}13 \\
(8.9 \%)\end{array}$ & 146 \\
\hline
\end{tabular}

Offences against the person were recorded in $24(16 \%)$ cases, and they included common assault, usually assaults on policemen, grievous bodily harm, carrying an offensive weapon, writing a threatening letter, threatening behaviour, and manslaughter. Property offences (53\%) were clearly the largest group ; they comprised suspected persons, loitering with intent, larceny or attempted larceny, malicious or wilful damage, men found on enclosed premises, trespassing, breaking and entering, receiving, credit by fraud. In order to categorize the gravity of offences and attempt to correlate these diagnoses, the property offences were divided into three subcategories: minor where the value was under $£ 10$, moderate where it was valued at between $£ 10$ and $£ 50$, and major when the value was over $£ 50 ; 78 \%$ were of the minor variety and only $6 \%$ of the major. The latter included "taking and driving," and arson. Sexual offences accounted for $9 \%$; schizophrenia was diagnosed in four cases of indecent exposure; other cases included a hypomanic and two of anxiety state in coloured immigrants. The most serious charges were those of rape and indecent assault (homosexual); both of these were thought to be cases of personality disorder.

Sixty-three patients had previously been sentenced to prison; 20 had had over 10 previous convictions (Table IX). The high incidence of a previous prison sentence could be expected in the psychopaths; it was more surprising in the subnormal group. Relatively fewer with schizophrenia, manic depression, and neurotic reaction had been in prison before, but some of those who had been in prison had often been ill for a long period and had spent some years intermittently in prison. For example, in three schizophrenic patients, each with more than 10 previous convictions, the illness had gone unrecognized for many years. One patient with a clear psychiatric history of schizophrenia since childhood and a particularly strong family loading of that condition had had nine previous convictions and nine sentences, including sentence to approved school, Borstal, and prison. Another patient had spent 15 years almost continuously in prison, and at the time of examination showed florid schizophrenic symptoms, in each case the illness being untreated. Approximately a third of the whole group had been disposed of previously by the courts under a Hospital Order, commonly Section 60 of the Mental Health Act, 1959 (Table X). Two-thirds of the subnormal group had been under a Hospital Order ; half of the schizophrenics and manic-

\begin{tabular}{|c|c|c|c|c|c|c|}
\hline \multicolumn{7}{|l|}{ TABLE IX. } \\
\hline \multirow{2}{*}{\multicolumn{2}{|c|}{ Diagnosis }} & \multicolumn{5}{|c|}{ No. of Previous Offenc } \\
\hline & & 0 & $1-3$ & $4-10$ & $11+$ & Total \\
\hline $\begin{array}{l}\text { Schizophrenia } \\
\text { Manic depression } \\
\text { Neurotic reaction } \\
\text { Organic/senile } \\
\text { Psychopathy } \\
\text { Subnormal .. } \\
\text { N.A.D. . . }\end{array}$ & $\begin{array}{l}\because \\
\therefore \\
\therefore \\
\therefore \\
\cdots\end{array}$ & $\begin{array}{r}17 \\
4 \\
9 \\
2 \\
6 \\
0 \\
2\end{array}$ & $\begin{array}{r}25 \\
5 \\
7 \\
2 \\
7 \\
2 \\
3\end{array}$ & $\begin{array}{r}13 \\
1 \\
2 \\
0 \\
11 \\
5 \\
3\end{array}$ & $\begin{array}{r}3 \\
0 \\
3 \\
0 \\
12 \\
2 \\
0\end{array}$ & $\begin{array}{r}58 \\
10 \\
21 \\
4 \\
36 \\
9 \\
8\end{array}$ \\
\hline Total & . & $\begin{array}{c}40 \\
(27 \cdot 4 \%)\end{array}$ & $\begin{array}{c}51 \\
(34 \cdot 9 \%)\end{array}$ & $\begin{array}{c}35 \\
(24 \cdot 0 \%)\end{array}$ & $\begin{array}{c}20 \\
(13 \cdot 7 \%)\end{array}$ & 146 \\
\hline
\end{tabular}

depressives and less than a quarter of the psychopaths and those with neurotic reactions had been dealt with in this way. Of the 50 men who had previously been dealt with on a Hospital Order nearly one-half (23) had also been given a prison sentence in the past, which concurs with the findings of Rollin (1965).

TABLE X.-Relation between Criminal Background and Diagnosis and between Hospital Orders and Diagnosis

\begin{tabular}{|c|c|c|c|c|c|c|}
\hline \multirow[t]{2}{*}{ Diagnoses } & & \multirow{2}{*}{$\begin{array}{c}\text { First } \\
\text { Offence }\end{array}$} & \multicolumn{2}{|c|}{$\begin{array}{l}\text { Previously } \\
\text { in Prison }\end{array}$} & \multicolumn{2}{|c|}{$\begin{array}{c}\text { Previously on } \\
\text { Hospital Order }\end{array}$} \\
\hline & & & Yes & No & Yes & No \\
\hline $\begin{array}{l}\text { Schizophrenia } \\
\text { Manic depression } \\
\text { Neurotic reaction } \\
\text { Organic/senile } \\
\text { Psychopathy } \\
\text { Subnormal . . } \\
\text { N.A.D. . }\end{array}$ & $\begin{array}{l}\cdots \\
\because \\
\cdots \\
\cdots \\
\cdots\end{array}$ & $\begin{array}{r}17 \\
4 \\
9 \\
2 \\
6 \\
0 \\
2\end{array}$ & $\begin{array}{r}16 \\
2 \\
7 \\
1 \\
26 \\
7 \\
4\end{array}$ & $\begin{array}{r}42 \\
8 \\
14 \\
3 \\
10 \\
2 \\
4\end{array}$ & $\begin{array}{r}25 \\
5 \\
4 \\
1 \\
8 \\
6 \\
1\end{array}$ & $\begin{array}{r}33 \\
5 \\
17 \\
3 \\
28 \\
3 \\
7\end{array}$ \\
\hline Total & $\ldots$ & 40 & 63 & 83 & 50 & 96 \\
\hline
\end{tabular}

\section{Discussion}

The catchment area concerned in this survey-the catchment area of Long Grove Hospital, which is a large part of the East End of London-is an area of considerable social disorganization with a heavy proportion of the population in the lower socio-economic group. The hospital intake from the prison and courts was similar enough, socially and intellectually, to mix with the ordinary hospital intake from other sources, and they were nursed, in general, in a mixed-sex open ward. No serious difficulties arose from this arrangement, either from the nursing staff or from the patients.

The recognition given to psychopathic disorder by the Mental Health Act, 1959, may have advanced its further understanding and treatment. The Act defines psychopathic disorder as " a persistent disorder ... of mind ... . which results in abnormally aggressive or seriously irresponsible conduct ... and which requires or is susceptible to medical treatment." It allows the psychopath below the age of 25 to be dealt with under various hospital orders in the same way as the mentally ill. The number of persons with personality disorders, including psychopathy, among those referred to court is in my view increasing. Most of them presented with depressive illnesses and had a past history of such reactions. They commonly conformed to the "unstable drifters" of MayerGross, Slater, and Roth (1954) who, when faced with minor stress, react with anxiety (especially in the coloured immigrants) or with depression, and, less commonly, with other neurotic reactions. The group has a strong resemblance to that described by West (1963) as the "passive inadequate deviant," which accounted for about half the chronic prison population he analysed. This suggests that the chronic male prison population and men remanded for psychiatric opinion have much in common. Other evidence of this overlap accrues from the number of schizophrenic patients seen who had been in prison before and been previously remanded for psychiatric opinions. Scott (1960) does not make a clear distinction between the psychopath and the chronic offender. Only 10 of the group were chronic alcoholics, most of them were not addicts. It was surprising that more alcoholics were not referred for a psychiatric opinion considering the numbers seen in the East London courts and the numbers admitted to hospital generally.

The offences committed by the personality disorders group tended to be more serious than those of the schizophrenic patients ; in the latter, offences were, with few exceptions, trivial. Serious violence occurred, however, as often in schizophrenia (two cases) and in depression (two cases) as in psychopathy (two cases). The latter were the " unsocialized, aggressive psychopaths" of Hewitt and Jenkins (1946).

A mixture of mental illness and delinquency in the coloured immigrant population in the prison study highlights their cultural and racial difficulties. Four cases exemplified the 
panic-reaction described by Lambo (1962) as the " malignant anxiety state"; two cases required to be nursed in a padded room in prison, both being finally unconvicted of sexual offences; the panic reaction appeared to stem directly from the arrest. The precipitation of schizophreniform episodes in prison is also worthy of comment ; five cases illustrated this with sudden hallucinations and delusions, deriving from the stress of imprisonment.

Magistrates seem unable to tolerate much psychiatric disturbance in court. The indifference and inattention of the schizophrenic are sometimes regarded as wanton behaviour, and a mild hypomanic outburst is treated as contempt of court.

\section{Conclusions}

The large majority of men referred for psychiatric report and seen by me in 1963 suffered from schizophrenia (40\%) and personality disorders (39\%). Neurotic states, especially depression and anxiety, were a common complication of psychopathy. Hypomania was not uncommon, nor were panic reactions in coloured men reacting to stress. Social factors contributed to the incidence of criminal behaviour in the mentally ill; the offence was often a cry for help and was committed when the men felt that they needed treatment or when they, or their relatives for them, were unable to obtain it. Ten per cent. of the homeless who were referred had left good homes on account of their illness and had drifted into a state of social isolation, confirming the views of many psychiatrists regarding the drift of schizophrenic patients. The understanding of the mentally ill by police and the courts still seems poor, and the strict operation of the law in regard to these patients appears to be cumbersome. The period in remand in prison might be better used for a fuller psychiatric and social assessment, and treatment facilities in prison seem urgently needed.

The treatment recommended by psychiatrists and prison medical officers is often in the nature of social rehabilitation, which is difficult to arrange from prison, often necessitating hospital admission in the absence of hostel accommodation. The role of the psychiatrist in making recommendations to courts is to suggest disposal of a patient rather than to determine the degree of responsibility for his offence. The number of men coming to the out-patient department after a psychiatric interview in prison but without a specific recommendation for treatment being made to the courts is noteworthy. Many more of those with personality disorders could have been admitted to hospital at the time had treatment facilities been available.

\section{Summary}

A study of 146 consecutive men who were referred from courts and prisons for a psychiatric opinion in one year is reported. Medical and social aspects are discussed. The most common diagnostic categories were schizophrenia (40\%) and personality disorders (39\%)-the latter often associated with neurotic reactions. Frequently more than one diagnosis was made; or an intractable social problem was apparent which seemed to contribute to the criminal behaviour. Possibly an increasing number of psychopaths are being referred because of the provisions of the Mental Health Act, 1959.

In $77 \%$ a previous psychiatric history was found, and $43 \%$ had been given a previous prison sentence. Six per cent. were newly diagnosed schizophrenics: a number of floridly ill men had spent many years in prison without treatment.

The offences committed were usually of nuisance value only, except for six which were very serious. The majority of men were offered some form of psychiatric help, and in general the recommendation for treatment was accepted by the court; in a few cases where it was not accepted the patients needed to be admitted to hospital shortly afterwards, often during a prison sentence. I questioned the need for so many men being remanded in custody for a psychiatric report.

\section{REFERENCES}

Brooke, E. M. (1962). Lancet, 2, 1211.

Hewitt, L. E., and jenkins, R. L. (1946). Fundamental Patterns of Maladjustment. Springfield.

Lambo, T. A. (1962). 7. ment. Sci., 108, 256.

Mayer-Gross, W., Slater, E., and Roth, M. (1954). Clinical Psychiatry. Cassell, London.

Rollin, H. R. (1963). Brit. med. 7., 1, 786.

Sco (1965). Ibid., 1, 831.

Scott, P. D. (1960). Ibid., 1, 1641

West (1964). Ibid., 1, 1117.

West, D. J. (1963). The Habitual Prisoner. Macmillan, London.

Bearcroft, J. S., and Smith, A. (1960). Int. F. soc. Psychiat., 6, 34.

\title{
Thyrotoxicosis and Gigantism Associated with "Klinefelter's Syndrome"
}

\author{
RAYMOND GREENE,* D.M., F.R.C.P. ; WILLIAM SINGER,* M.B., B.S.
}

Brit. med. F., 1965, 2, 1523-1525

Abnormally rapid growth occurs sometimes in thyrotoxicosis but is uncommonly the major symptom. The combination of gigantism and thyrotoxicosis has not previously been described in association with a chromosomal abnormality.

\section{Case Report}

The patient, a white boy of 15 , was brought to the clinic because of excessive growth and retarded sexual development. He complained of dyspnoea on exertion but had no other symptoms of thyrotoxicosis. Scholastically he was about three years behind his contemporaries. As a child he had been lethargic: he first walked at $2 \frac{1}{2}$ and first talked at $3 \frac{1}{2}$ years. He had not suffered from any serious illnesses. He had grown 8 in. $(20 \mathrm{~cm}$.) in two years, the normal increase in this period being from 5 to 6 in. $(12.5$ to $15 \mathrm{~cm}$.).

* Department of Endocrinology, New End Hospital, London.
On examination he was a very thin boy, 76 in. $(193 \mathrm{~cm}$.) in height and weighing $121 \mathrm{lb}$. $(54.9 \mathrm{~kg}$.). The normal height for his age (Polani's chart) was 56 to 71 , average $64 \frac{1}{2}$ in. (142 to 180 , average $164 \mathrm{~cm}$.). He had pectus excavatum. The penis was small and the testicles were soft and the size of cherries. The pubic hair was sparse and of feminine distribution. There was no facial or axillary hair. The thyroid was just palpable. The pulse rate was 93 . There were no other features suggestive of thyrotoxicosis.

Investigations.-Serum protein-bound iodine (P.B.I.) $11.6 \mu \mathrm{g} . /$ $100 \mathrm{ml}$. $\mathrm{T}_{3}$ (red-cell uptake) $25.7 \%$ (normal 15-20\%). " $\mathrm{T}$ " (urinary excretion of ${ }^{131} \mathrm{I}$ ) $100+$ (normal 3-13). B.M.R. $+23 \%$. Urinary steroids: 17-ketosteroids $5.8 \mathrm{mg} . / 24$ hours, 17-hydroxycorticosteroids $21.2 \mathrm{mg} . / 24$ hours. Urinary follicle-stimulating hormone (F.S.H.) 96-384 mouse units/24 hours. The bone age corresponded with the chronological age.

He was thought to be suffering from thyrotoxicosis, exhibiting an unusual rate of growth with curiously few features suggestive of this diagnosis. As there were signs of early puberty, it was decided not to treat his hypogonadism at this stage. 